\title{
The Naxalite Movement in India
}

Ayesha Kapedia

Fourth Year Paper

Citation Style: Chicago

For almost fifty years, parts of India have been struggling with the violent actions of the Naxalite movement. What started out as a peasant uprising in 1967 in the West Bengal village of Naxalbari, has today become India's largest and most dangerous Maoist movement. Mostly active in the eastern regions of India, the Naxalites have been fighting for socialist change and agrarian reform for the past four decades. The use of violence on the part of the Naxalites has given it the reputation of being a violent terrorist group. The key to understanding the Naxalites lies not only in their support base and their actions, but also their failures, which continue to hold them back. While the rest of the country has transitioned into the $21^{\text {st }}$ century, the Naxalites continue to dwell in the past. The Naxalite movement has lost sight of their intended goals and today, the movement remains active yet structurally outdated.

As mentioned earlier, the Naxalite movement began in 1967 with the communist revolutionaries in India seeking reforms within society. In 1964, the communist movement in India experienced it first divisions within the community. Disagreements between the MarxistLeninist and Maoist communists led to the spilt of the communists and the creation of the Communist Party of India (Marxist-Leninist) (CPI-ML). ${ }^{1}$ The uprising in the village of Naxalbari was a result of the frustration with the local economic system. To better understand the reasons behind the rebellion we must take a look at the demographics and the social structure of Naxalbari in the 1960's.

According to census reports of $1961,58 \%$ of the population of Naxalbari were part of the schedule Castes and tribes. However, these were not the important members of society. Instead, the group known as tribals held much of the power. The tribals were mainly wealthy landowners, also known as jotedars, whereas the people of the schedule castes and tribes worked

\footnotetext{
${ }^{1}$ Partha Mukherji, "Study of Social Conflicts: Case of Naxalbari Peasant Movement", Economic and Political Weekly, Vol.22, No.38, (Sept. 19, 1987): 1610
} 
as cultivators and agricultural labourers on the jotedars' lands. Many of the peasants were also employed on tea gardens, forests, and mines. Since the peasants never owned any of the land they cultivated, they were often faced with the threat of eviction by the jotedars. The Estates Acquisition Act of 1953 which was passed by the government put a limit on the amount of land that could be possessed by a land owner. As a result, several land owners began to sell off their excess land which resulted in evictions. ${ }^{2}$ It is in this environment that the peasant uprising began to gain momentum. Although the rebellion was easily squashed by the police forces, it did become a landmark moment in Indian history, which came to shape the future activities of the Maoist movement in India. ${ }^{3}$

The events in Naxalbari, successfully planted the seeds for a movement that would continue to grow even after the uprisings were so easily shot down. One of the major reasons for the expansion and success of the Naxalite movement over the next few years was its appeal among the underprivileged, the outcasts and the peasants of society. The Naxalites were triumphant in voicing the demands of the landless and the peasants in a way that Indian society had never experienced before. They were able to successfully involve the peasantry who became active players in the movement. ${ }^{4}$

The Naxalites were also one of the first revolutionary groups within India to justify the use of violence as a means to achieve their cause. By fighting aggressively against the Indian state, the Naxalites set a precedent for future movements. The political discourse in India has ever since been shaped through the use of violence, with other movements in Punjab, Kashmir and Assam also taking up arms. ${ }^{5}$

While the popularity for the Naxalite movement is slowly in decline today, in the state of Bihar it remains one of the strongest political forces. Today Bihar is one of the only states where the Naxals have found great support, and where the social struggle is showing signs of success. The Naxalites have been fighting to change tenancy laws, while also fighting for a system known as batai-the equal share of land for landlords and tenants. They have also fought to put in place

\footnotetext{
${ }^{2}$ Prakash Singh, "The Naxalite Movement in India”, (New Delhi: Rupa and Co., 2006): 5-7

${ }^{3}$ Ibid: 13

${ }^{4}$ Sumanta Banerjee, "Naxalbari: Between Past and Future", Economic and Political Weekly, Vol.37, No. 22, (Jun. 1-7, 2002): 2115-2116

${ }^{5}$ Sumanta Banerjee, "Naxalbari: Between Past and Future": 2116
} 
rights to minimum wage. Labourers have seen an increase in wages, and in some cases, women are also receiving equal pay. The movement has also been fighting for the poor to have equal access to common property resources, such as full access to local ponds, for fishing. ${ }^{6}$ Politically, the poor in central Bihar now view themselves as having the same political power and rights as their landlords. Further, the poor are now also freely able to exercise their vote. ${ }^{7}$

However, the Naxalites have made the most progress in fighting for freedom of expression. Fighting for ones dignity and honour is seen as being a vital social freedom. Although the dalits of the region continue to face discrimination, there is a growing sense of confidence and autonomy. The Naxalites have successfully fought to have the dalits recognized as individuals and human beings. Labourers are free to sell their labour to whoever they wish, and children are free to attend schools. The wealthy landowners are no longer able to exercise their power unlawfully. ${ }^{8}$ There has also been a significant decrease in the number of rapes against lower caste women. The fight for the Dalit community is similar to what the lower caste communities have been fighting for. Similar to the Naxals, in 1972 a Marxist group known as the Dalit Panthers came into the limelight in the state of Maharashtra and began to pursue the interests of the Dalit masses. ${ }^{9}$ In Maharashtra as in Bihar, the leftist movements used the issue of caste and discrimination to fight for social reforms.

While the state of Bihar may seem like a success story for the Naxalites, it is important to note that is remains an anomaly. Aside from the accomplishments in Bihar, the movement has failed to gain popularity within the rest of India in the recent years. According to some scholars, this can be attributed to certain ideological and systematic flaws on the part of the Naxal leaders.

Arguments have been raised that the initial goal of social liberation and revolution has taken a backseat to violence, and that the Naxalite war has almost entirely become a military one. Seeing as police presence is so strong in the Naxalite occupied regions, continuous effort is spent resisting law enforcement. As a result, much of the financial resources are used towards the purchase of sophisticated weaponry. As a way of protecting themselves, the Naxals have often

\footnotetext{
${ }^{6}$ Bela Bhatia, "The Naxalite Movement in Central Bihar", Economic and Political Weekly, Vol.40, No.15, (Apr.915, 2005): 1542-1543

${ }^{7}$ Ibid: 1544

${ }^{8}$ Ibid

${ }^{9}$ Deepa S. Reddy, “The Ethnicity of Caste”, Anthropological Quarterly, Vol.78, No.3, (Summer, 2005): 552
} 
turned to illicit activities such as extortions and the murder of innocent people. The ambitions of economic and political reform have been replaced with offensive military actions. In the process, the movement is slowly isolating the local peasantry from the cause. ${ }^{10}$

As well, in the $21^{\text {st }}$ century, an ideological crisis has threatened the movement. A movement originally inspired by the teachings of Mao Tse-tung, popular during the 1930's and 1940's, the outdated values no longer have significance in a world that is moving faster towards a neo-liberal model. The collapse of the Soviet Union and China's shift towards a market economy, have in a way rendered the socialist movements of today almost obsolete. In this sense, some scholars argue that the Naxalites are fighting for an archaic model of socialism. What may have been successful in China during the early part of the $20^{\text {th }}$ century, can no longer be applied in modern India. ${ }^{11}$ This is especially evident when one examines the recent cases of farmer suicides and the economic policies that are the factors behind this issue. India's agrarian policy has seen a major shift towards corporate farming. Although currently corporations do not have a monopoly over the Indian farming sector, they have successfully taken over other sectors such as marketing, inputs, outputs and in some cases, even water provisions. ${ }^{12}$ With major Western powers around the world shamelessly promoting neo-liberal agendas, it is clear that India is quickly moving away from any form of socialist policy it may still harbour from its past. As a result, it is easy to see how the Maoist ideologies would clash with the current direction India is moving in.

As mentioned earlier, in recent years the Naxalite focus has shifted more towards self defence and less on social change. As a result, the movement has failed to garner mass public support. Some scholars argue that in recent decades, the movement has become an almost insignificant political force, losing its position to other extremist groups. Focussing excessively on underground activities, the Naxalites have failed to politicize the rest of civil society. Unlike other groups such as the Sangh Parivar, the BJP and the RSS, which have dominated civil society, the Naxalites have been all too happy to remain in their familiar surroundings. Since religion is a critical part of Indian society, the poor who were supporters of the Maoist

\footnotetext{
${ }^{10}$ Sumanta Banerjee, "Naxalbari: Between Past and Future": 2116

${ }^{11}$ Sumanta Banerjee, "Naxalbari: Between Past and Future": 2116

12 P. Sainath, "Neo-liberal Terrorism in India: The Largest Wave of Suicides in History" Counterpunch (2009) http://www.counterpunch.org/2009/02/12/the-largest-wave-of-suicides-in-history/
} 
movement, were easily swayed by other groups that not only addressed the economic disparities but also played on the power of religion. ${ }^{13}$

Religion was never part of the socialist rhetoric of the Naxalite. Thus, although the Leftist movement in India was successful in uniting the poor based on their economic woes, it never quite succeeded in helping the poor overcome their religious differences. It is in this situation that groups such as the Sangh Parivar, BJP and the RSS filled the gap. Not only did they bring together masses based on their social issues, but they were also united based on their religious beliefs. Throughout their campaigns and struggles, the Naxalites failed to address the obvious religious divides and tensions that played out in Indian society. Therefore, with the rise of Hindu communalism and rising religious tensions during the 1990's, many Muslim supporters also left the Naxal cause to join Islamic groups. ${ }^{14}$

Four decades since the inception of the Naxalite movement, what we have observed is a faction still caught in the past. While the Naxalites historically started out strong, they have failed to maintain their influence. Deviating from their initial goals and failing to address the religious dynamics within society has prevented them from achieving their social reforms. Although the movement has tasted success in parts of India such as Bihar, it largely remains an outdated menace for the Indian government. If any real triumph is to be attained, then a fundamental remodelling of the Naxalite cause is necessary. Expansion into a wider political arena, innovative organizational strategies and a new broad based socialist rhetoric are factors which could potentially lift this movement out of its slump. ${ }^{15}$ Until these changes are made, the Naxalites will continue to exist as a resistance group against the Indian government rather than a revolutionary movement.

\footnotetext{
${ }^{13}$ Sumanta Banerjee, "Naxalites: Time for Introspection”, Economic and Political Weekly, Vol.38, No.44, (Nov. 17, 2003): 4636

14 Ibid:

15 Sumanta Banerjee, "Naxalbari: Between Past and Future": 2116
} 


\section{Bibliography}

Banerjee, Sumanta, "Naxalbari: Between Past and Future" Economic and Political Weekly, Vol. 37, No.22, (Jun 1-7, 2002): 2115-2116।

Banerjee, Sumanta, "Naxalites: Time for Introspection" Economic and Political Weekly, Vol.38, No.44, (Nov. 1-7, 2003): 4635-4636

Bhatia, Bela, "The Naxalite Movement in Central Bihar" Economic and Political Weekly, Vol.40, No.15, (Apr. 9-15, 2005): 1536-1549

Mukherji, Partha, "Study of Social Conflicts: Case of Naxalbari Peasant Movement" Economic and Political Weekly, Vol. 22, No.38, (Sept. 19, 1987): 1607-1617

Reddy, Deepa S., "The Ethnicity of Caste” Anthropological Quarterly, Vol.78, No.3, (Summer, 2005): 543-584

Sainath, P., "Neo-Liberal Terrorism in India: The Largest Wave of Suicides in History" Counterpunch (2009) http://www.counterpunch.org/2009/02/12/the-largest-wave-ofsuicides-in-history/

Singh, Prakash, “The Naxalite Movement in India”, (New Delhi: Rupa and Co., 2006) 